\title{
AS RAÍZES DO BRASIL NO ESPELHO DE PRÓSPERO
}

PEDRo MEIRA Monteiro

\section{RESUMO}

O espelho de Próspero é um passo a mais na paixão latinoamericanista que une autores tão diversos como Darío, Martí, Rodó, Mariátegui, Manoel Bonfim, Sérgio Buarque de Holanda ou Gilberto Freyre - toda uma linhagem, enfim, a conceber o espaço fantástico de uma "outra" América, pensada ou sentida no contraste com o grande irmão do Norte. O espelho norte-americano refunda, desde o século XIX, a geografia shakespeariana que impressionou Sérgio Buarque e que porventura o assombraria enquanto concebia, na aventura do exílio, Raízes do Brasil. Embora esse ensaio clássico não seja explicitamente referido n'O espelho de Próspero, parece razoável supor que o livro de Richard Morse seja uma espécie de reescritura de Raízes do Brasil, capaz de radicalizar a promessa ibero-americana que brilha, também, no horizonte de Sérgio Buarque de Holanda.

PALAVRAS-CHAVE: Richard Morse; Sérgio Buarque de Holanda; latino-americanismo; raizes ibéricas.

\section{ABSTRACT}

Prospero's Mirror is one further step in the Latin Americanist Passion that brings together authors such as Darío, Martí, Rodó, Mariátegui, Manoel Bonfim, Sérgio Buarque de Holanda and Gilberto Freyre - a whole lineage of writers who delineate the fantastic space of "another" America, thought of, and felt, in contrast to her northern big brother. Beginning in the 19th century, a North American mirror reshapes the Shakespearean geography which impressed Sérgio Buarque de Holanda, and which would haunt him while he composed Raízes do Brasil in exile. Even though Holanda's classic book is not explicitly used in Prospero's Mirror, one can think that Morse's own book is a sort of re-writing of Raizes do Brasil, going into more depth in the IberoAmerican promise that also shines in Buarque de Holanda's horizon.

KEYWORDS: Richard Morse; Sérgio Buarque de Holanda;

Latin Americanism; Iberian roots.

[1] Apud Agamben, Giorgio. Estâncias: a palavra e o fantasma na cultura ocidental. Trad. Selvino José Assmann. Belo Horizonte: Editora da UFMG, 2007.
Para os pais de nossos pais uma casa, uma fonte, uma torre desconhecida, até mesmo seu próprio vestido, seu manto, ainda eram infinitamente mais, infinitamente mais familiares; quase cada coisa um vaso, no qual já encontravamo humano e acumulavam ainda mais do humano. Agora chegam da América coisas vazias e indiferentes, aparências de coisas, simulacros de vida... Uma casa na acepção norte-americana, uma maçã norte-americana ou uma videira de lá nada têm em comum com a casa, a fruta e o cacho em que haviam penetrado a esperança e a meditação dos nossos antepassados...As coisas animadas, vividas, admitidas em nossa confiança, vão declinando e já não podem ser substituídas. Talvez sejamos nós os últimos que ainda ten hamos conhecido tais coisas...

Rainer Maria Rilke, carta a Witold von Hulewicz, $1912^{1}$. 
Em um pequeno ensaio sobre Edgar Allan Poe, o poeta nicaragüense Rubén Darío recorda sua chegada aos Estados Unidos, através da baía de Nova York. O cenário é todo mirífico, brumoso ("En una mañana fría y húmeda llegué por primera vez al inmenso país de los Estados Unidos"), convidando o leitor ao descobrimento de uma paisagem repleta de significados: a metrópole que se insinua entre ilhas, o país que se abre às vistas, sem que se lhe possa resistir.

Há um momento, em especial, em que vale a pena prestar atenção: espremido entre a imensidão de Long Island e a silhueta de Staten Island, antes ainda que a paisagem férrea de Manhattan se revelasse, a beleza tentava, segundo o poeta, "al lápiz, ya que no, por la falta de sol, la máquina fotográfica”. Aí se encontra, porventura, um bom ponto de partida para as inquirições "americanistas" que, nunca é demais insistir, sugerem uma poética especular, isto é, a América que se descobre diante da América, buscando na grandiosidade acachapante do Norte o seu duplo desejado e temido, repudiado (como é claro na poesia e na prosa de Darío) mas também admirado.

A admiração se dá, nessa cena inicial, em meio à algaravia do ladrante slangyanqui, quando o lápis, não a máquina fotográfica, é chamado a desenhar o que só o poeta é capaz de ver. Em lugar do simples registro mecânico da luz - definição estrita e restritiva da fotografia - é o lápis que se convida ao desenho livre e formador. Este, justamente, o traçado que importaria compreender.

O que vêem poetas e ensaístas quando vislumbram essa outra América? Que espelho sedutor e terrível é esse? Como imaginam ou intuem uma América outra, supondo-a una por vezes, querendo-a resistente quase sempre? Como se delineia, pelas vias da imaginação, um território que responde com orgulho (e medo) àquela América que o engenho de Darío vislumbra na ciclópica Nova York, "la irresistible capital del cheque"? O que une intelectuais tão diversos em torno de uma diferença que, uma vez postulada, transforma-os quase em agentes demiúrgicos do discurso nacional e regional, reveladores privilegiados dos segredos da coletividade?

Na provocação venenosa do poeta que adentra o território inimigo, escutam-se já, como que prefigurados, os ecos de todos os arielismos que viriam a marcar tão fundo a imaginação latino-americana. Tal imaginação, isto é, a fantasia intelectual (ou dos intelectuais) sobre a América Latina, ou Ibero-América, era introduzida por Darío antes ainda de Rodó, quando, no referido ensaio sobre Poe, publicado originalmente em 1894, o poeta sugeria que do lado de lá do espelho era Caliban quem reinava:

"Esos cíclopes...", dice Groussac; "esos feroces calibanes...", escribe Peladan. ¿Tuvo razón el raro Sar al llamar así a estos hombres de la América del 
[2] Darío, Rubén. "EdgarAllan Poe: fragmento de um estudio". In: Los raros. Buenos Aires: Espasa-Calpe, 1952, p. 20 . Sobre o imaginário arielista, com especial atenção dirigida a Darío, cf. Jáuregui, Carlos. “Calibán, ícono del 98: a propósito de un artículo de Rubén Darío". Revista Iberoamericana, vol. 64, no $184-85,1998$, pp. 441-49.
Norte? Calibán reina en la isla de Manhattan, en San Francisco, en Boston, en Wáshington, en todo el país. Ha conseguido establecer el imperio de la materia desde su estado misterioso con Edison, hasta la apoteosis del puerco, en esa abrumadora ciudad de Chicago. Calibán se satura de whisky, como en el drama de Shakespeare de vino; se desarrolla y crece; y sin ser esclavo de ningún Próspero, ni martirizado por ningún genio del aire, engorda y se multiplica; su nombre es Legión. Por voluntad de Dios suele brotar de entre esos poderosos monstruos, algún ser de superior naturaleza, que tiende las alas a la eterna Miranda de lo ideal. Entonces, Calibán mueve contra él a Sicorax, y se le destierra o se lo mata. Esto vió el mundo con EdgarAllan Poe, el cisne desdichado que mejor ha conocido el ensueño y la muerte...2.

Das entranhas do monstro, do tecido saturado de vícios carnais, da terra regida pela vil matéria, nasce uma flor mórbida, um dos "raros" que tanto encanta a esse Darío que, invocando-os, encontra para si mesmo um abrigo sob o resplandecente arco dos simbolistas e decadentes, dos excêntricos amantes da mais refinada forma do espírito, que a sociedade burguesa punha a perder com sua sucessão ímpia de bens que se igualam e se reproduzem. A mercadoria, terror dos verdadeiros poetas, era então o grande inimigo. E seu nome era legião.

Valeria a pena lembrar o quão especial é esse Poe que emerge das leituras de Darío, tão baudelairiano, afinal. Mas antes ainda, seria interessante pensar nas variantes sociológicas que, bem alinhavadas, poderiam talvez esclarecer algo desse espírito excêntrico, que esconde uma crença profunda na diferença social, na exceção que a um só tempo separa os intelectuais do resto e, paradoxalmente, os torna aptos a representar aquilo mesmo de que eles se separaram. Entretanto, meu objetivo aqui é outro: procuro perceber como podem estabelecer-se as linhas de força de um discurso sobre o território americano que, supondo a Europa dividida entre um além e um aquém-Pireneus, termina por projetar uma América rasgada também por uma divisa fundamental.

As perguntas que se lançam então sobre a unidade ibero-americana, e que terminam por despertar as personagens shakespearianas para que falem de um mundo novo, são inquirições que não recaem apenas sobre uma suposta presente diferença. Desenha-se aí, na investigação de agora, uma pergunta sobre o futuro - o futuro dos povos, nada menos que isso - disparada no exato momento em que o olhar do Sul penetra o território imaginário que, a acreditarmos no poeta, apenas a liberdade dada a um lápis excepcional poderia circunscrever. 
Antes porém de chegar a Sérgio Buarque de Holanda e Richard Morse, que juntos compõem o foco de minha investigação, convém lembrar que a própria referência shakespeariana tem sua história.

Em estudo iluminador, Chantal Zabus traça aquela "Calibanic genealogy" que deságua na recuperação crítica e poética do selvagem, permitindo supor que, na inversão dos valores (Caliban suplantando Ariel e, sobretudo, subvertendo o poder de Próspero), ocorra um gesto de fundamental importância. A autora de Tempests after Shakespeare associa tal gesto à imaginação pós-colonial, que teria possibilitado a Aimé Césaire, por exemplo, em Une tempête (1969), reler Shakespeare à sombra de uma já quase secular recuperação calibanesca, cuja origem inequívoca é o drame philosophique de Renan, Caliban, suite de $\mathrm{La}$ Tempête, de 18783 .

Antes porém do deprivileging of Prospero que transformaria Caliban numa espécie de herói pós-colonial — tão saboroso ao paladar da teoria contemporânea que domina hoje a academia norte-americana - é Ariel, como se sabe, que podia também despertar o interesse e a admiração do intelectual que vive às margens, isto é, que desde o Sul olha para o Norte, num estranho jogo de encantamento e desencantamento. A estranheza do jogo tem a ver com o fato de que, negando à América do Norte o seu poder de sedução, e afirmando o encanto exclusivo das promessas que se engendram ao Sul, se está, no fundo e na forma, sublimando as promessas que o Norte secreta. Na matemática dos afetos e desafetos, a afirmação do desencanto pode ser a ocultação de um momento de deslumbre, e o medo, no fim das contas, de gostar daquilo que a boa consciência ensina a refutar. Resta-nos sempre perguntar, justamente, pelo quantum de encantamento que se esconde na postulação de um mundo desencantado que, insisto, a boa consciência manda associar ao Outro, não a nós mesmos. Um Outro que, neste caso, segue sendo o gigante que despeitadamente cresce ao norte, despertando, um a um, os fantasmas da dominação.

É a dominação, precisamente, e o temor de uma força inimiga, gigantesca e avassaladora, que dão partida à imaginação desse outro espaço que, na longa duração do pensamento social, nos faz pensar, antes ainda da Ibero-América, numa América latina que, projetando-se desde o Sul dos Estados Unidos (ou daquilo que viria a ser o território dos Estados Unidos da América), permitiria a muitos intelectuais que sonhassem, mais ou menos vagamente, com uma gloriosa e imbatível linhagem romana.

Muito já se discutiu sobre a origem imperialista e francesa do conceito, masé com regozijo que diversos intelectuais postulam a unidade do subcontinente latino-americano, ou - respeitando o campo metafórico oitocentista - é com júbilo que pensam numa "raça" exclusiva $e$, por menos que o saiba o restante do mundo, superiort. Ao menos é
[3] Cf. Renan, Ernest. Caliban, suite de La Tempête. Paris: Calmann Levy, 1878. Cf. também Zabus, Chantal. Tempests after Shakespeare. Nova York: Palgrave, 2002.

[4] Dilma Diniz sugere que o conceito tenha sido inaugurado por Charles Calvo em 1862 ("O conceito de América Latina: uma perspectiva francesa". Anais do XI Encontro Regional da Abralic. São Paulo: Abralic, 2007). Jorge Schwartz, entretanto, supõe que o termo América Latina surja "pela primeira vez em 1836, em artigo de Michel Chevalier, retomado com vigor pelo escritor e diplomata colombiano José María Torres Caicedo" em 1865. A idéia de que "América Latina" fora uma expressão cunhada pelos ideólogos de Napoleão III como justificativa para a invasão do México não passaria, ainda, de um erro (Schwartz, Jorge. "Abaixo Tordesilhas!”. In: Rocha, João Cezar de Castro (org.). Nenhum Brasil existe: pequena enciclopédia. Rio de Janeiro: Topbooks/UniverCidade, 2003, pp. 847-48). Para um debate abrangente da lógica imperial que preside o conceito de hispanoamericano, ver Díaz Quiñones, Arcadio. "Hispanismo y guerra". In: Sobre los principios: los intelectuales caribeños y la tradición. Bernal: Universidad Nacional de Quilmes, 2006,pp. 65-166. 
[5] Castro, Belén. "Introducción". In: Rodó, José Enrique. Ariel. Madri: Cátedra, 2004, p. 53.

[6] Cf. Machado de Assis, Joaquim Maria. Memórias póstumas de Brás Cubas. Rio de Janeiro: Nova Aguilar, 1997, pp. 515-16 (Obras Completas, vol.1).

[7] Díaz Quiñones, Sobre los principios, op.cit., p.131. assim que uma consciência crioula amiúde reage a certo europeísmo elitista, é assim, sabemos, que se funda um gosto pelo local que, reatualizando a fábula romântica e retirando-lhe um pouco do exoticismo, resultaria, no Brasil, no gosto modernista e em seus muitos galhos nacionalistas que florescem a partir de 1922, estendendo-se à esquerda e à direita.

Mantenhamo-nos um pouco, porém, em torno daquilo que precede o modernismo brasileiro. Ainda no que toca ao quadrante hispanoamericano, em seu prefácio à edição Cátedra do Ariel de José Enrique Rodó (1900), Belén Castro propõe um esquema preciso para a compreensão desse sentimento latino-americano que tem sua origem no século retrasado:

Esse latino-americanismo oitocentista se sustenta sobre três fatores de grande impacto na mentalidade da época: a visão romântica do "gênio das nações", cifrado na herança de raça, língua e religião; as teorias raciológicas e eugênicas do século, e a pujança crescente dos Estados Unidos, que já havia ocupado parte do México por volta de 1840 e ambicionava conquistar novas posições na América Central e no Panamá. Frente aos anglo-saxões que desceram do Mayflower, esgrimem uma genealogia cultural e espiritual que remonta a Rômulo e Remo, e começa assim a desenvolver-se uma relação diferente com a metrópole espanhola, despojada já de suas últimas possessões americanas. A "madrasta" opressora de outros tempos, agora arruinada economicamente e desarmada politicamente, começará a ser vista como provedora de um tesouro humanístico (a língua, a arte, a literatura) que atualiza a ancestralidade da latinidade clássica e cristã em que se fundamenta a identidade ameaçada dos criollos hispano-americanoss.

Diante de tal atualização da "ancestralidade da latinidade clássica", suponho que um leitor brasileiro se sentirá especialmente convidado, ou autorizado, a desfechar um olhar irônico sobre a descendência gloriosa de que "nós" faríamos parte. Trata-se afinal de uma linhagem e, como bem sabem os leitores de Machado de Assis, a fixação segura da linhagem, seja ela a dos tanoeiros, seja a dos latinos, invariavelmente esconde um pouco de burla... ${ }^{6}$.

De uma forma ou de outra, tratemo-lo com mais ou menos circunspecção, ei-nos aqui no coração do hispanismo que Arcadio Díaz Quiñones associou indelevelmente, numa ampla recontextualização do período finissecular, à guerra e ao seu "referente silencioso" que são os Estados Unidos. Para o crítico portorriquenho, por trás da busca desses pais fabulosos, que deviam compensar imaginariamente a ameaça do invasor, desenrola-se uma freudiana "novela familiar", com a substituição dos pais por "personas más grandiosas"7. Eé com Rodó, exatamente, mas já no Mirador de Próspero, de 1913, que podemos ver 
a redução do conceito e a inclusão definitiva do Brasil nos quadros mentais do continente:

No necesitamos los sudamericanos, cuando se trate de abonar esta unidad de raza, hablar de una América Latina; no necesitamos llamarnos latinoamericanos para levantarnos a un nombre general que nos comprenda a todos, porque podemos llamarnos algo que signifique una unidad mayor mucho más intimay concreta:podemos llamarnos "iberoamericanos", nietos de la heroica y civilizadora raza que sólo politicamente se ha fragmentado en dos naciones europeas; y aun podríamos ir más allá y decir que el mismo nombre de hispanoamericanos conviene a los nativos de Brasil' .

Alinhagem que imaginariamente amalgama essa raça, seja ela mais ou menos cósmica, é longa, e ainda no contexto especificamente brasileiro ela incluiria nomes do quilate de Joaquim Nabuco ou Manoel Bonfim, para não avançar ainda aos ensaístas da década de 1930, nem ao geral antiamericanismo que seguiria conformando a imaginação da intelectualidade brasileira, e que a voz contrastiva de um Monteiro Lobato não faria mais que paradoxalmente reforçar.

Não cabe aqui, tampouco, arrolar os inúmeros autores hispanoamericanos que caminham, com maior ou menor solenidade, a via dessa idealização de uma América latina, ou mais especificamente ibérica. Atenho-me apenas, dentro dos limites deste artigo, à idéia desse sentimento interior, essa "unidad íntima" a que se refere Rodó, e que um leitor de Sérgio Buarque de Holanda associará imediatamente à sentença cortante de Raízes do Brasil: "o americano ainda é interiormente inexistente" 9 .

A falta desse duplo referente - uma América nuestra e os próprios americanos - resulta, evidentemente, numa busca apaixonada, mas fadada, talvez desde o início, ao fracasso, atravessada como vai pela ambigüidade da refutação de um Outro que é também um objeto de estima inconsciente. Atendo-nos apenas ao campo literário, que se pense na maravilha de ambivalência, de amor e desamor pelos Estados Unidos, que são os textos de José Martí para La Nación de Buenos Aires, escritos em especial desde a ciclópica Nova York ${ }^{10}$.

A invenção de uma genealogia, ainda que não adentremos minúcias filosóficas, tem a ver com certo deslumbramento e delírio diante de um centro irradiador, apontando no limite para aquilo que Foucault chamava "a morte da interpretação", isto é, a crença absoluta "de que há signos, signos que existem primordialmente, originalmente, realmente, como marcas coerentes, pertinentes, e sistemáticas" ${ }^{11}$.
[8] Rodó. “Iberoamérica”, apudDíaz Quiñones,Sobrelosprincipios, op.cit., pp.131-32.

[9] Holanda, Sérgio Buarque de. Raizes do Brasil. São Paulo: Cia das Letras, 2006, p. 189 .

[10] Martí,José.Enlos Estados Unidos: periodismo de 1881 a 1892 . Madri:ALLCAXX, 2003 (col.Archivos).

[11] Foucault, Michel. "Nietzsche, Freud, Marx". In: Dits et écrits, 19541975. Paris: Gallimard, 2001, pp. 601-2. 
[12] No âmbito da chamada teoria pós-colonial, um ensaio iluminador sobre a pertinência do signo é o de Homi Bhabha (cf. "DissemiNation: time, narrative and the margins of the modern nation". In: Nation and narration. Londres: Routledge, 1990 , pp. 291-322).

[13] A sentença ("o americano ainda é interiormente inexistente") aparece associada ao nome de $\mathrm{D}$. $\mathrm{H}$. Lawrence - "um dos poetas mais singulares de nosso tempo", dirá Sérgio Buarque -, em cujos Studies in classic American literature o escritor brasileiro encontrará a idéia de que "na atividade americana o sangue é quimicamente reduzido pelos nervos" (Holanda, op. cit., pp. 189, 222).

[14] Para a consideração de uma "sutil sublimação do bandeirismo" na obra de Sérgio Buarque de Holanda, ver Bosi, Alfredo. "Colônia, culto e cultura”. In: Dialética da colonização. São Paulo: Cia das Letras, 1992, p. 29.
Arigor, a crença nesse signo original levaria à estagnação da consciência, mas talvez seja exatamente nesse ponto, em que a interpretação se aproxima de sua própria "morte", que a riqueza da busca, embora fadada ao fracasso, vem à luz, e não apenas como resultado literário, ou poético. Ou antes, no resultado poético dessa impossível busca identitária estão cifradas questões importantíssimas que apontam para o social: quem se inclui no signo da coletividade, quem é o autor da saga coletiva, quais são as vozes autorizadas a falar em nome da comunidade, quem está à margem e quem está no centro do signo? O que está fora dele, enfim? E se está fora, por que é necessário evocá-lo, sempre que se evoca a própria "raça"12?

Quanto à crença em uma raça americana - essa raça em que, na senda dos leitores de Martí, Sérgio Buarque de Holanda deve ter pensado antes de declarar que não havia ainda uma entidade americana formada ${ }^{13}$ - , haverá o paradoxo, de sabor bem "latino-americano", que está na postulação de uma identidade coletiva a basear-se, afinal, na impureza da mescla e do encontro. Os leitores mais entusiastas verão aí o elogio do hibridismo, que é um solo tão fértil para a imaginação, e que "nós" brasileiros conhecemos tão bem, porque tivemos a provável ventura de vê-lo lavrado, a partir da década de 1930, por alguém do talhe de Gilberto Freyre.

Convém sempre, no entanto, perguntar pelo que resta fora dessa construção identitária de um povo alegremente "mestiço". Em outras palavras, deve-se evitar esquecer quanta violência e quantos encontros infelizes se sublimam no elogio do encontro das culturas, nessa postulação, enfim, de uma civilização americana ${ }^{14}$. Lembremos as palavras finais de Próspero-Rodó, exemplares, sob muitos aspectos:

Aún más que para mi palabra, yo exijo de vosotros un dulce e indeleble recuerdo para mi estatua de Ariel. Yo quiero que la imagen leve y graciosa de este bronce se imprima desde ahora en la más segura intimidad de vuestro espíritu. Recuerdo que una vez que observaba el monetario de un museo, provocó mi atención en la leyenda de una vieja moneda la palabra Esperanza, medio borrada sobre la palidez decrépita del oro. Considerando la apagada inscripción, yo meditaba en la posible realidad de su influencia. ¿Quién sabe qué activa y noble parte sería justo atribuir, en la formulación del caráctery en la vida de algunas generaciones humanas, a ese lema sencillo actuando sobre los ánimos como una insistente sugestión? ¿Quién sabe cuántas vacilantes alegrías persistieron, cuántas generosas empresas maduraron, cuántos fatales propósitos se desvanecieron, al chocar las miradas con la palabra alentadora, impresa, como un gráfico grito, sobre el disco metálico que circuló de mano en mano?... Pueda la imagen de este bronce - troquelados vuestros corazones con ella - desempeñar en vuestra vida el mismo inaparente pero decisivo papel. Pueda ella, en las horas sin luz del desaliento, reanimar en 
vuestra conciencia el entusiasmo por el ideal vacilante, devolver a vuestro corazón el calor de la esperanza perdida. Afirmado primero en el baluarte de vuestra vida interior, Ariel se lanzará desde allí a la conquista de las almas. Yo le veo, en el porvenir, sonriéndoos con gratitud, desde lo alto, al sumergirse en la sombra vuestro espiritu. Yo creo en vuestra voluntad, en vuestro esfuerzo; y más aún, en los de aquellos a quienes daréis la vida y transmitiréis vuestra obra. Yo suelo embriagarme con el sueño del día en que las cosas reales harán pensar que ila Cordillera que se yergue sobre el suelo de América ha sido tallada para ser el pedestal definitivo de esta estatua, para ser el ara inmutable de su veneración!15.

Mais uma vez, aqui, a "intimidad" desempenha importante papel. Porém, o que sevê na cena final de Arieléeloqüente, e penso que bastante: um mestre que desperta a suprema esperança em seus discípulos e em seguida se retira. O gesto de retirar-se consigna a "conquista de las almas", lançada como repto a uma elite espiritual, agente civilizadora do Novo Mundo. $\mathrm{O}$ aspecto estetizante desse gesto não escaparia sequer a Unamuno ${ }^{16}$.

O apelo da passagem e do gesto atingiu também, no ano de 1920, um jovem de 17 anos que escreveria e publicaria, no Correio Paulistano, graças à intermediação de seu mestre Affonso Taunay, um artigo intitulado "Originalidade literária". Em seu primeiro texto publicado na imprensa, Sérgio Buarque de Holanda defendia a "emancipação intelectual" que, no seu entender, prescindia da emancipação política, como o provaria o caso sintomático de Mistral ${ }^{17}$. Um dos autores imediatamente evocados pelo jovem articulista é o peruano Francisco García Calderón, um arielista de primeira plana, preocupado, conta-nos Sérgio, com a "completa emancipação espiritual do Novo Mundo, e, em especial, na porção onde domina a língua de Cervantes".

Um texto seguinte de Sérgio Buarque de Holanda, já então com 18 anos completos, publicado na Revista do Brasil de maio de 1920,é uma resenha de Ariel, que faz também as vezes de um obituário do recémfalecido Rodón ${ }^{18}$. O artigo é um verdadeiro grito contra a decadência das nações que, desde tempos antigos, se ajoelham diante da grandeza e do progresso de outras nações, pertencentes a "raças" exóticas. A reminiscência do passado serve a desenhar o alvo do autor, que entusiasticamente comunga nas desconfianças difusas de Rodó em relação aos norte-americanos. O "utilitarismo yankee" é o seu grande vilão, e o jovem brasileiro não deixa de associá-lo à condição republicana dos Estados Unidos, deixando entrever, com claridade, seus próprios ideais monarquistas ${ }^{19}$.

O elitismo patente de Rodó ganha, na resenha do genial adolescente, um espectro amplo:
[15] Rodó, Ariel, op. cit., pp. 229-30.

[16] Castro, op. cit. Ver também, é claro, o clássico de Ángel Rama ( $L a$ ciudad letrada. Hanover, NH: Ediciones del Norte, 1984).

[17] Holanda, "Originalidade literária". In: O espírito e a letra. São Paulo: Cia das Letras, 1996, vol. 1, pp.35-41.

[18] Idem. "Ariel". In: O espirito e a letra, op. cit., pp. 42-46.

[19] Sobre o monarquismo do jovem Sérgio Buarque, cf. Eugênio, João Kennedy. "Um horizonte de autenticidade. Sérgio Buarque de Holanda: monarquista, modernista, romântico (1920-1935)". In: Monteiro, P. M. e Eugênio, J. K. (orgs.). Sérgio Buarque de Holanda: perspectivas. Campinas/ Rio de Janeiro: Editora da Unicamp/ Eduerj, 2008,pp.425-59. 

dos da Inglaterra. Notara o grande filósofo germânico [Emil Strauss] que a seus patrícios aparecem aquelas repúblicas, dotadas de um realismo grosseiro, de um empirismo frio e prosaico e que, ao serem eles transportados a seu solo, falta-lhes essa atmosfera delicada que haviam respirado em sua pátria. Nos Estados Unidos, há, além do mais, um ar infecto de corrupção que exala das classes que governam, dificil de ser encontrado na Europa. O utilitarismo e a preocupação de ganhar dinheiro, a auri sacra fames, conquistaram os norte-americanos em detrimento do espírito intelectual, da moralidade politica e da própria liberdade individual. Isso deu azo a que Schopenhauer os qualificasse de proletários da humanidade. Seu caráter próprio, diz ele,é a vulgaridade sob todas as formas: moral, intelectual, estética, vulgaridade que se manifesta não somente na vida privada mas também na vida pública. O autor de Die Welt als Wille atribuía essa vulgaridade em parte à Constituição republicana dos Estados Unidos e, em parte, à sua origem, isto é, a terem sido no princípio uma colônia penitenciária ou por possuírem por ascendentes, "homens que tinham razões para fugir da Europa"2o.

Seria, é claro, um equívoco gritante associar essas palavras à crítica profunda ao pensamento autoritário que Sérgio Buarque elaboraria, dezesseis anos depois, em Raízes do Brasil. Mas vale a pena reter, para fim de contraste, essa impressão forte que, no jovem de 18 anos, a causa latinoamericana despertara. E o "empirismo frio e prosaico" norte-americano não deixaria de reaparecer, embora atenuado, nas teses weberianas que fornecem, ao que tudo indica, os andaimes em que se arrima a argumentação de Sérgio Buarque, que retoma, no célebre capítulo sobreo "homem cordial", a "contribuição ao mundo" que Ribeiro Couto propusera em seu

[21] Venho desenvolvendo uma pesquisa em que procuro explorar o diálogo "latino-americano" em que se sustenta a formulação do "homem cordial" que, lembremos, é uma figura que Ribeiro Couto criara num pequeno artigo para a revista $M o n-$ terrey, editada pela Embaixada do México no Rio de Janeiro. Cf. Couto, Rui Ribero. "El hombre cordial, producto americano". In: Sérgio Buarque de Holanda: perspectivas, op. cit., pp. 397-38. Sobre a presença weberiana na imaginação de Sérgio Buarque de Holanda, cf. Machado, Brasil Pinheiro. "Raízes do Brasil: uma releitura", ibidem, pp. 155-80; Monteiro, Pedro Meira. A queda do aventureiro: aventura, cordialidade e os novos tempos em Raízes do Brasil. Campinas: Editora da Unicamp, 1999. diálogo indireto com o diplomata e ensaísta mexicano Alfonso Reyes ${ }^{21}$.

De toda forma, convém reter a idéia de que uma triangulação fundamental marca a imaginação do "latino-americano", ou daquilo que, no espectro que une Sérgio Buarque de Holanda a Richard Morse, seria nomeado, mais precisamente, ibero-americano.Assim como, no âmbito do hispanismo, a reconstrução imaginária das raízes ibéricas fornece um contrapeso importante para o orgulho ferido pela guerra no Caribe e pela conquista norte-americana de territórios antes "hispânicos", ou, regressando ainda mais no tempo, funciona como uma espécie de antídoto ao caráter imperialista da doutrina Monroe, também o Brasil, pensado nesse amplo contexto americano, tinha a sua parte na afirmação de uma identidade que ao fim reforçava a divisão da América em duas. Em outros termos, não há conceituação ou imaginação poética das origens, e nem mesmo há fantasia possível de um corte definitivo das raízes, sem a postulação de um terceiro ângulo em que, abrindoseem vértice, projetam-se os Estados Unidos e sua constante ameaça à integridade do mundo que se agita ao Sul do Rio Grande. 
Ainda no mesmo ano de 1920, numa poderosa invectiva contra os Estados Unidos publicada n' A Cigarra, o jovem Sérgio Buarque reagiria duramente à "quimera do monroísmo", que vinha levando muitos de seus compatriotas a encontrar, na sombra norte-americana, um antídoto benfazejo a "todas as tentativas de colonização que porventura hajam por bem empreender, no Novo Mundo, as potências européias" 22 .É curioso, porém, que o jovem articulista já destacasse aí o jogo do desejo, que é feito de atração e recusa. Chama a atenção o tom ligeiramente destoante em relação às certezas de seu anti-ianquismo, no remate de seu artigo: "Deve ter-se sempre em vista que a doutrina de Monroe muito se assemelha àquela dama que inspirou a Maciel Monteiro os célebres versos:Quempode ver-te sem quereramar-te?/Quem pode amar-te sem morrer de amores?"23.

A recuperação dos sensuais versos românticos dá conta do movimento que vou tentando explorar aqui: a mescla de horror e atração, sempre que se trata desse Outro norte-americano. Para além do tópos do belo horrível, ou do imaginário medúseo que a mesma sensibilidade romântica iria recriar, está a tentação profunda que todo monstro desperta.Aqui, o jovem parece apoiar-se irrestritamenteem sua crença anti-ianquista, mas é verdade que, inadvertidamente talvez, deixa ver o encantamento que o outro lado exerce. Encantamento mortal, que faz de novo pensar na projeção do monstruoso ora sobre o Outro ao Norte, ora sobre o Outro ao Sul.

A fortuna do arielismo é um tema complexo e extenso, cujo tratamento, aqui, nos desviaria demasiado o rumo. Convém, entretanto, somar o nome de Sérgio Buarque de Holanda ao cenário desses leitores de Shakespeare que parecem muitas vezes tomar ao pé da letra a horrenda caracterização do savage and deformed slave, essa criatura danada que, no módulo de leitura que une Rodó a Sérgio, ressuma o utilitarismo norte-americano.

Em todo caso, a investigação do arielismo e de sua fortuna nos obrigaria a olhar com atenção redobrada a inversão dos sinais, naquele momento em que as simpatias se deixam carrear para o lado de Caliban, como no caso formidável, em que pese certo travo ideologizante, do "Caliban" de Roberto Fernández Retamar, já um espécime, a seu modo, do Caliban "pós-colonial" a que se refere Chantal Zabus²4.

Contudo, a inversão dos sinais que associam a Ibero-América ora aos poderes espirituais de Ariel, ora a um Caliban ressignificado pelas lutas pós-coloniais, esconde o fato de que, em ambos os casos, o "antídoto ao anglo-materialismo" cumpre, nas palavras de José Guilherme Merquior, uma mesma função psicológica, a qual terá levado o crítico liberal a imaginar, no calor da hora de um acendrado debate em torno deOespelho de Próspero, que o "calibanismo de Morse vinga, oitenta anos depois, o arielismo de Rodó" 25 . É mister, por fim, ir um pouco mais a
[22] Holanda. "A Chiméra do Monroismo".A Cigarra, 1 jul. 1920.

[23] Ibidem.

[24] Fernández Retamar, Roberto. Todo Caliban. Buenos Aires: CLAC$\mathrm{SO}, 2004$.

[25] Merquior, José Guilherme. "O outro Ocidente". Presença, no 15 , 1990, p. 71. 
[26] Retomo, nesta seção, argumentos desenvolvidos em texto anterior. Cf. Monteiro. "Buscando América". In: Holanda, Raizes do Brasil, op. cit., pp. 313-34 (versão em espanhol, "Buscando a América”. Prismas: Revista de Historia Intelectual, $\mathrm{n}^{\circ} 11,2007$, pp. 43-55).

[27] Eis a arquireferida passagem: "A ascese cristã, que de início fugira do mundo para se retirar na solidão, a partir do claustro havia dominado eclesiasticamente o mundo, enquanto a ele renunciava. Ao fazer isso, no entanto, deixou de modo geral intacta a vida cotidiana no mundo com seu caráter naturalmente espontâneo. Agora ela ingressa no mercado da vida, fecha atrás de si as portas do mosteiro ese põea impregnarcom sua metódica justamente a vida mundana de todo dia, a transformá-la numa vida racional no mundo, não deste mundo, não para este mundo"(Weber, Max. A ética protestante e o "espirito" do capitalismo. Trad. José Carlos Mariani de Macedo. São Paulo: Cia das Letras, 2004, p.139).

[28] É interessante contrastar as reflexões relativamente serenas de "Considerações sobre o americanismo", originalmente publicado em 1941 e depois incluído em Cobra de vidro, ao ácido anti-americanismo daqueles artigos de juventude que acabo de referir (cf. Holanda. "Considerações sobre o americanismo". In: Cobra de vidro. São Paulo: Perspectiva, 1978, pp. 23-27). fundo nessa inversão, compreendendo como, subjacente a ela, trabalha surdamente o programático encantamento pelo "outro" lado, por aquela criatura do Sul que a malícia de Próspero pôs a perder, mas que outros leitores, de outros livros etempos, podem redescobrir, advogando, mais ainda que sua causa, sua suposta Mensagem remissora.

No jogo daquela triangulação que permite ver o espaço latinoamericano numa tensão sucessiva com a Europa e a América do Norte, está a imaginação de duas Europas distintas, cuja linha divisória é representada, para todos os efeitos, pelos Pireneus. Entre eles e Gibraltar, teria se desenvolvido algo diverso daquilo que marca, ou teria marcado, a história do restante da Europa. E aqui ingresso propriamente em Raizes do Brasil.

Sabemos que a "cultura da personalidade" é o traço fundamental com que Sérgio Buarque de Holanda desenha um de seus personagens centrais: o homem ibérico ${ }^{26}$. Poderíamos dizer que a atrofia da esfera pública é o resultado lógico de uma personalidade inflada: em terra de infindáveis barões, o pacto político consome-se em relações de lealdade ou ódio. Seguindo o torneio metafórico de fundo claramente organicista, são "os elementos anárquicos" que frutificam, enquanto as "forças ativas" (o adjetivo não consta da primeira edição do livro) se perdem num universo de paixões individuais imperiosas. Assomam aí os traços de uma imaginada outra América, que teria a ver com um paradigma civilizacional diverso, infenso às origens do liberalismo e resistente ao apagamento, ou à contenção, das paixões individuais. Na imaginação plausivelmente weberiana de Sérgio Buarque de Holanda, a entrega ao mundo nunca se deu, entre gente ibérica, por meio da anulação ou sublimação dos poderes e apetites do indivíduo. Jamais terá havido entrega àquela dimensão que, originalmente religiosa, terminaria por laicizar-se, até o ponto em que o indivíduo mergulha com todo fervor no mundo do trabalho. Momento em que o ascetismo foi levado para fora dos mosteiros, segundo a imagem célebre de Weber ${ }^{27}$.

Como se sabe, a concepção do capitalismo proveniente de tal visão tem como referência a Europa reformada, mas é uma alusão constante àquela "América" que assombrara também Weber e que, em Raizes do Brasil, é uma referência oblíqua, nem sempre revelada. Contudo, os Estados Unidos seguem a fornecer o espelho incômodo de uma experiência supostamente bem-sucedida, relegando os brasileiros (aqui próximos aos hispano-americanos) a um plano em que se descobrem o reflexo ou o desdobramento de outra realidade e outra Europa. Outra Europa, outra América ${ }^{28}$. 
Vemo-nos, a partir daí, diante da formação imaginária de dois mundos ou, nos termos de Sérgio Buarque de Holanda, de duas éticas: o trabalho e a aventura. A partir do contraste entre eles, podemos formular a pergunta de fundo que espreita o leitor de Raízes do Brasil: que pacto poderá estabelecer-se a partir de uma ética da exploração máxima da terra, da mobilidade extrema dos homens, da valorização da força instantânea do indivíduo? Que comunidade política se fundaria a partir de uma experiência como essa? Estamos porventura diante do ponto em que a análise de Sérgio Buarque toca, mau grado seu, interpretações diversas, de cunho deliberadamente econômico: o problema é também da ordem da acumulação, da formação de uma comunidade nacional capaz de gerir o que produz ${ }^{29}$. Entretanto, o princípio organizacional da sociedade a projeta longe da satisfação de suas próprias "forças ativas", que mergulham numa desordem inquietante.

Como resposta possível - paradoxal, mas lógica - à desordem, resta a entrega irrestrita do indivíduo a uma força superior que ele teme. Não havendo uma ética fundada nas formas agremiadoras do trabalho constante e metódico, a única disciplina concebível está na obediência absoluta a uma instância externa ao homem. Daí o "prodígio de racionalização" que foram as missões jesuíticas, como se lê no primeiro capítulo de Raízes do Brasil. Daí a sombra contra-reformista que se projeta sobre a experiência política ibérica.

A "desordem", lato sensu,é o elemento-chave que dispara, na imaginação política tradicional, a necessidade das forças ordenadoras, como se o corpo social pudesse manter-se íntegro graças apenas ao controle das sementes de dissolução que nele se expõem perigosamente. Esta é, exatamente, a matriz do pensamento conservador contra a qual se levanta o inquérito de Sérgio Buarque de Holanda. Em 1936, a crermos no historiador, a "simples obediência" já caducara como princípio de disciplina, mas, ao mesmo tempo, era naquele solo esclerosado que vicejavam as ideologias autoritárias mais torpes, e a justificativa de, a todo custo, "superar os efeitos do nosso natural inquieto e desordenado" 30 .

Uma análise detalhada de Raizes do Brasil poderia revelar os diálogos com as correntes ideológicas do tempo. Ao final do livro, a pena de Sérgio Buarque de Holanda selevanta, briosa, contra o "mussolinismo indígena" que era o "nosso" integralismo, mas também, de forma mais sutil, deixa repercutir sua queixa contra todo pensamento ordenador que deita mira ao "inquieto e desordenado", às "essências mais íntimas", ao "nosso próprio ritmo espontâneo" que, lidos fora de contexto, parecerão talvez demasiado misteriosos, ou apenas irracionais. Que ritmo, que essências? Para a boa compreensão deste passo faz-se mister um corte modernista, porque aí se cruzam - para utilizar com
[29] Refiro-me aqui à matriz de uma explicação clássica sobre a condição do "atraso" e suas raízes coloniais, cuja origem aponta para Caio Prado Jr. e se estende a Celso Furtado (cf. Prado Jr., Caio. Formação do Brasil contemporâneo. São Paulo: Brasiliense, 1961 [1942]).

[30] Holanda, Raízes do Brasil, op. cit., p. 30 . 
[31] Cf.Lafetá,João Luiz.1930: a crítica e o modernismo. São Paulo: Editora 34,2000 .

[32] O diálogo entre o modernista e o historiador tem ensejado, nos últimos tempos, vários e bons trabalhos. Destaco Avelino Filho, George. "As raízes de Raízes do Brasil". Novos Estudos-Cebrap, $\mathrm{n}^{\circ} 18$, set. 1987 , pp. 3341; Prado, Antonio Arnoni. "Raizes do Brasile o modernismo". In:Trincheira, palco e letras: crítica, literatura e utopia no Brasil. São Paulo: Cosac \& Naify, 2004, pp. 263-70; Castro, Conrado Pires de. Com tradições e contradições: contribuição ao estudo das raizes modernistas do pensamento de Sergio Buarque de Holanda. Campinas: dissertação de mestrado, IEL/Unicamp, 2002; Carvalho, Marcus Vinicius Corrêa. Outros lados: Sérgio Buarque de Holanda, crítica literária, história e política (1920-1940). Campinas: tese de doutorado, IFCH/Unicamp, 2003. certa liberdade as categorias críticas de João Luiz Lafetá — os projetos "estético" e "ideológico" do autor ${ }^{31}$.

Defato, Raízes do Brasil se abre para a discussão de impasses candentes numa sociedade que vivia o embate entre valores liberais e inspirações totalitárias, num momento em que se experimentavam formas de associação política e laboral que anulavam experiências anteriores, alimentando o veio personalista da história política latino-americana. Nesse aspecto, é um livro que se detém sobre o presente e interroga o futuro. Mas, ao mesmo tempo, Raizes do Brasil se escreve olhando para trás, erguendo a ponte que conecta a juventude modernista ao momento presente, quando já se abandonaram algumas das miragens iniciais do movimento, sem que no entanto houvesse arrefecido por completo seu espírito, ou quando menos, no caso de Sérgio Buarque de Holanda, sem que se tivesse apagado totalmente o crítico literário da década anterior ${ }^{32}$.

Muito breve eesquematicamente, pode-se dizerque "O lado oposto e outros lados", artigo publicado em 1926 na Revista do Brasil, é o corte fundamental na carreira do jovem crítico, quando se lançam algumas das idéias que dez anos depois apareceriam, já mediadas pela experiência alemã, em Raizes do Brasil. Naquele artigo, numa atitude bem pouco cordial, Sérgio Buarque manda ao diabo a diplomacia, ao criticar duramente os modernistas academizantes que, julgando dominar a "expressão nacional", nada mais fariam que impor a sua hierarquia ao universo das artes, atualizando uma atitude ilustrada que o modernismo pretendera, justamente, deitar por terra. Não discuto aqui em detalhe a complexa rede de diálogos que se deixa entrever nesse artigo. Basta apenas lembrar que, por trás do alvo aparente formado por Ronald de Carvalho e Guilherme de Almeida, estava Alceu Amoroso Lima, mas estava também a sombra enorme, ainda incômoda, do paternal e velho Graça Aranha.

Sérgio Buarque conclamava seus fantasmas para exorcizá-los. “O lado oposto e outros lados" traz uma esplêndida discussão sobre os partidários da ordem, de um lado, e os que, desde "outros lados", desconfiavam de toda ordenação e apostavam fundo na espontaneidade, compreendida como a "liberdade" que os resguardaria de quaisquer tentações autoritárias. Interessante que a mesma espontaneidade que o jovem modernista reclamava em 1926 reaparecerá depois, em Raízes do Brasil, como o elemento-chave a obstar os planos autoritários dos que pretendessem "organizar" a "nossa desordem", como se lê no último parágrafo do livro.

Há, entre Raízes do Brasil e aquele artigo, coincidências importantes. Vale a pena ler com atenção o jovem e polêmico autor a queixarse longamente, em "O lado oposto e outros lados", dos partidários da ordem: 
[...] gente bem-intencionada e que esteja de qualquer modo à altura de nos impor uma hierarquia, uma ordem, uma experiência que estrangulem de vez esse nosso maldito estouvamento de povo moço e sem juízo. Carecemos de uma arte, de uma literatura, de um pensamento enfim, que traduzam um anseio qualquer de construção, dizem. E insistem sobretudo nessa panacéia abominável da construção. Porque para eles, por enquanto, nós nos agitamos no caos e nos comprazemos na desordem. Desordem do quê? É indispensável essa pergunta, porquanto a ordem perturbada entre nós não é decerto, não pode ser a nossa ordem; há de ser uma coisa fictícia e estranha a nós, uma lei morta, que importamos, senão do outro mundo, pelo menos do Velho Mundo. É preciso mandar buscar esses espartilhos pra que a gente aprenda a se fazer apresentável e bonito à vista dos outros. O erro deles está nisso de quererem escamotear a nossa liberdade que é, por enquanto pelo menos, o que temos de mais considerável, em proveito de uma detestável abstração inteiramente inoportuna e vazia de sentido33.

É interessante compararo "estouvamento de povo moço e sem juízo", lavrado pelo jovem autor (aqui com 24 anos), ao "natural inquieto e desordenado" de seu livro de estréia. Em ambos os casos, trata-se de reclamar e defender um ritmo, ou um pulso, que resistisse aos delírios idealizantes dos arquitetos políticos (em Raízes do Brasil) ou dos construtores da arte nacional (no artigo de 1926). Em ambos os casos, a "reforma" que propõem os partidários da ordem é, no fundo, nada mais que uma reação, ou uma "sutil contra-reforma", como ironicamente sugere o ensaísta, ao referir-se à possibilidade de que o fascismo encontrasse guarida entre os brasileiros.

No escopo ainda das origens ibéricas, discutidas especialmente no primeiro capítulo de Raízes do Brasil, parece que o impasse, a um só tempo estético e ideológico, desenha-se entre os dois extremos que uma cultura da personalidade ensejaria, pois que a

[...] vontade de mandar e a disposição para cumprir ordens são-lhes [aos povos ibéricos] igualmente peculiares. As ditaduras e o Santo Ofício parecem constituir formas tão típicas de seu caráter como a inclinação à anarquia è̀ desordem. Não existe, a seu ver, outra sorte de disciplina perfeitamente concebível, além da que se funde na excessiva centralização do poder e na obediência 34 .

Está em jogo a vontade de obedecer e mandar, sempre em função dos valores (estéticos ou ideológicos) que, espelhados num céu de certezas, se estendem como uma tábua imutável, eternamente idêntica a si mesma. O imaginário escolástico impõe-se desde o primeiro capítulo de Raízes do Brasil:
[33] Holanda. "O lado oposto e outros lados". In: O espirito e a letra, op. cit., p. 226.

[34] Idem, Raizes do Brasil, op. cit., p. 29. 
[35] Ibidem, pp. 23-24.

[36] O princípio tomista ("Cum enim gratia non tollat naturam, sed perficiat, oportet quod naturalis ratio subserviat fidei; sicut et naturalis inclinatio voluntatis obsequitur caritati", Summa Theologiae, I, q.1, a.8, ad.2) sugere que a distância daquele céu ideal não impede, antes enseja, o aperfeiçoamento do mundo natural pela luz da revelação. O incômodo de Sérgio Buarque de Holanda se dá, é claro, no momento - contemporâneo - em que uma caprichosa engenharia social se torna o agente do aperfeiçoamento político. Em termos tomistas, a doutrina sagrada não é matéria de argumentação, porque se assim fosse ela viria da razão ou da autoridade, $o$ que lhe roubaria a dignidade. Mas, como se lê na resposta a tal objeção, de onde provém a citação de Sérgio Buarque, a doutrina sagrada pode também basear-se em argumentos de autoridade, porque ao fim é imperativo que acreditemos na autoridade daquele a quem a Revelação foi feita. Reduzir essa autoridade a uma anacrônica "paixão de professores" é, precisamente, o objetivo contemporâneo do ensaísta.
A Idade Média mal conheceu as aspirações conscientes para uma reforma da sociedade civil. O mundo era organizado segundo leis eternas indiscutíveis, impostas do outro mundo pelo supremo ordenador de todas as coisas. Por um paradoxo singular, o princípio formador da sociedade era, em sua expressão mais nitida, uma força inimiga, inimiga do mundo e da vida. Todo o trabalho dos pensadores, dos grandes construtores de sistemas, não significava outra coisa senão o empenho em disfarçar, quanto possivel, esse antagonismo entre o Espirito e a Vida (Gratia naturam non tollit sed perficit). Trabalho de certa maneira fecundo e venerável, mas cujo sentido nossa época já não quer compreender em sua essência. O entusiasmo que pode inspirar hoje essa grandiosa concepção hierárquica, tal como a conheceu a Idade Média, é em realidade uma paixão de professores 35 .

Entre o "supremo ordenador do mundo" e os "professores" encantados pela perfeição de suas próprias concepções, resta a diferença de que, para uma mentalidade medieval, a natureza estática dos valores podia ser um dado inquestionável e, no limite, produtivo ${ }^{36}$. É nesse sentido que se pode compreender o caráter "moderno" do influxo tridentino, como reação ao mundo que florescia mais ao norte, e que fundava uma outra concepção do indivíduo.

Recuperando a importância das polêmicas sobre o livre-arbítrio, que estão no centro da discussão religiosa e política da era moderna, Sérgio Buarque de Holanda lembra que "as teorias negadoras do livrearbítrio sempre foram encaradas com desconfiança e antipatia pelos espanhóis e portugueses". Sendo a personalidade o valor supremo entre gente ibérica, a "organização espontânea" torna-se difícil, e agora percebemos que a dificuldade não se deve apenas ao número excessivo de "barões". Trata-se, sobretudo, da dificuldade que sente o indivíduo em moderar seus gestos e adequar-se ao pacto da comunidade, aceitando por fim que as hierarquias não são, e não podem ser, obra a consumar-se definitivamente neste mundo.

Para essa personagem fantástica da imaginação buarquiana - 0 homem ibérico - a entrega individual não é a capitulação metódica ao trabalho perseverante do dia-a-dia.Antes, ela se guarda no gesto espetacular de prostrar-se diante de uma verdade superior que, encarnada num projeto ou numa pessoa, possa revelar-se neste mesmo plano em que vivemos, oferecendo um alívio definitivo a todos os males. No quadrante ibérico, para essa outra América, a salvação é obra política, conduzida por uma criatura excepcional.

Em Raizes do Brasil, há uma aporia nem sempre devidamente percebida ou explorada. De um lado, parece que a crítica modernista, atualizada naquele ensaio, pretende despejar toda sua munição sobre os partidários da "lei morta", aqueles que vão buscar a ordem ao "outro mundo", que é tambémo o "Velho Mundo", segundo o artigo de 
1926. De outro lado, há uma "alma comum" que vincula os brasileiros à progênie ibérica, de onde viria a "forma atual da nossa cultura" que, bem compreendida, nos aproximaria do que somos. O que somos é também, portanto, o outro mundo, o Velho Mundo. Em termos mais simples, haveria aí uma dupla e incongruente legitimação: da espontaneidade e da originalidade de um lado, e da identidade com o antecessor de outro. Trata-se de um imbróglio nitidamente modernista, e é natural que o jovem de 24 anos penda para a defesa apaixonada da autenticidade irreverente, enquanto o escritor mais maduro se descobre diante de uma cadeia de impasses, crente a um só tempo na originalidade e em seu contrário ${ }^{37}$.

Há, evidentemente, como que um encaminhamento lógico em Raízes do Brasil, que leva a imaginação ao extremo de uma "contribuição original" ao mundo, apontando para a realização de uma entidade coletiva singular. Mas a própria criatura original é vítima do vaticínio letal do autor: desbaratadas as condições históricas que lhe deram origem, o "homem cordial" desapareceráa ${ }^{38}$. A cordialidade é uma categoria evanescente que, no entanto, permanece e incomo$\mathrm{da}$, como se fora um resquício de que não podemos nos livrar, ou nos esquecer. Quiçá por trás dessas contradições se possa flagrar uma atitude modernista, notadamenteem sua versão antropofágica: revelar-se ao mundo seria o imperativo a exigir que nos acercássemos de um núcleo "nosso", desviante em relação à norma e resistente à permanência da linhagem, capaz de pervertê-la ao assimilá-la. Pouco importa que tal núcleo seja irreal: assim o é toda matéria de imaginação. Chamo a atenção, entretanto, para aquilo que, em Raízes do Brasil, aparece como um "ritmo espontâneo", ou como aquelas "essências mais íntimas" que desdenham as invenções humanas e ameaçam a arquitetura política mais caprichosa.

Mas o que faz com que o desvio, e com ele as tais forças ativas, desdenhosas das soluções ideais, sejam valorizados tão profundamente? Parece que o problema estaria em encontrar um singular "fluxo e refluxo" que não se limitasse a bulir a superfície, mas que pudesse revolver o subsolo.Aconversão desse potencial desvio, da suposta singularidade, em força construtiva,é um problema lógico intrincado, que encontra melhor solução no plano poético que no político. Há, na imaginação latino-americana, um poderoso e já velho desejo de valorização de forças autóctones que poderiam destruir pela base o cenário colonial, ou pós-colonial, americano. Mas há também, sempre, a pergunta angustiante sobre o que restaria após a destruição profunda, quando o desenraizamento tiver sido definitivamente consumado.

A conversão do excesso, ou da hybris tropical, em trunfo civilizatório, é uma invenção modernista cuja genealogia e cujo espectro valeria a pena pesquisar em detalhe, para além do que pode propor
[37] João Cezar de Castro Rocha detém-se sobre o sentido das alterações efetuadas no primeiro parágrafo de Raizes do Brasil, em cuja primeira edição se lê que constituíramos "o único esforço bem-sucedido em larga escala, de transplantação da cultura européia [...]", enquanto nas edições mais recentes o sucesso do transplante de tal cultura se tempera com circunstâncias naturais "se não adversas, largamente estranhas à sua tradição milenar" (cf. Rocha. "O exílio como eixo: bem-sucedidos $e$ desterrados. Ou: por uma edição crítica de Raízes do Brasil". In:Sérgio Buarque de Holanda: perspectivas, op. cit., pp. 245-75).

[38] Donde a facécia que encerra a carta a Cassiano Ricardo, publicada, em 1948, como resposta à leitura que o autor doMartim Cererê fizera do homem cordial: "E às vezes receio sinceramente que já tenha gasto muita cera com esse pobre defunto" (cf. Holanda. "Carta a Cassiano Ricardo". In: Raízes do Brasil, op. cit., p.396). 
[39] Cf. Santí, Enrico Mario. "Esta edición”. In: Ortiz, Fernando. Contrapunteo cubano del tabaco y el azúcar. Madri: Cátedra, 2002,pp.105-110.

[40]Cf., entre outros, Souza, Antonio Candido de Mello e. "A visão política de Sérgio Buarque de Holanda". In: Sérgio Buarque de Holanda: perspectivas, op. cit.

[41] Holanda. "O Estado totalitário". In: Barbosa, Francisco de Assis (org.). Raízes de Sérgio Buarque de Holanda. Rio de Janeiro: Rocco, 1989, pp. 298-301. este artigo. Tal investigação poderia muito bem conectar obras do modernismo brasileiro a congêneres hispano-americanas. Penso por exemplo, quanto à valorização da hybris, no que podem significar, no quadrante caribenho, os "furacões" para a sociologia de Fernando Ortiz ou para a ficção de Alejo Carpentier. Ou, num outro plano, poderia pensar-se no "estilo bárbaro" de Juan Francisco Manzano, que Enrico Mario Santí refere ao inscrever o mais célebre trabalho de Ortiz na grande tradição de uma escrita neobarroca hispano-americana, que bem se poderia compreender através da sensibilidade crítica do mesmo Carpentier, quando este sugere que "toda simbiosis, todo mestizaje, engendra un barroquismo". Ou mesmo, ainda na senda proposta por Santí, que se pense em Sarduy referindo-se a Lezama Lima è̀ sua frase neobarroca, "sintácticamente incorrecta a fuerza de recibir incompatibles elementos alógenos", o que revelaria, no plano poético, a "pérdida de la concordancia" 39.

A perda da concordância pode ser lida amplamente, dentro e fora do texto, como uma fascinação moderna que, nos países periféricos, engendra personagens que se antepõem à agenda européia, minando-a ou simplesmente corrompendo-a.

Entretanto, uma vez mais resta a sensação da imprecisão e do mistério que envolvem a natureza e as possibilidades daquelas "forças ativas", sempre prontas a resistir à engenharia especiosa da política tradicional. É tentador ler que aí está o "povo", e identificar, no Sérgio Buarque de Holanda de 1936, a radicalidade que the confere Antonio Candido40. Masétambém possível, sem prejuízo daquela análise,imaginar que o autor de Raizes do Brasil expusesse dilemas a que podemos responder hoje com uma serenidade que seria improvável à época.

Está por realizar-se, ainda, um balanço cuidadoso das inquietações que o debate sobre princípios liberais e totalitários podia provocar em Sérgio Buarque, quando escrevia Raizes do Brasil. As edições mais recentes trazem atenuadas observações sobre o caráter "fraudulento" (como figura em 1936) da "mitologia liberal", segundo a qual "os expedientes tirânicos nada realizam de duradouro". Não se trata, claro fique, de reclamar alguma fascinação original do ensaísta com os regimes de força - o que seria absolutamente um equívoco. Tratase apenas de atestar que antes do Estado Novo e da Segunda Guerra Mundial a crítica aos princípios liberais (em especial, como Sérgio Buarque escreve num artigo de 1935 sobre Carl Schmitt, a idéia de que "o Estado tende a ser um mero servidor da sociedade neutra, ou uma nova espécie de sociedade" 41 ) podia encontrar-se com a tese de que, afinal, a experiência ibérica na América constituíra um outro conceito do político, que o relativo sucesso ulterior do mundo liberal sepultaria por muito tempo (ou para sempre, no horizonte escatológico da imaginação neoliberal). 
É de toda forma significativo que, quase ao fim da vida, quando um editor lhe pediu que escrevesse um ensaio "atualizando suas idéias" para a versão francesa de Raízes do Brasil, Sérgio Buarque tenha tentado e não tenha conseguido fazê-lo, como mais de uma vez revelou em entrevista ${ }^{42}$. O fracasso da reescrita pode ter a ver com o vocabulário datado, com o vôo ensaístico que caíra em desgraça nos anos de 1970, ou simplesmente com a impossibilidade de escrever novamente o mesmo livro. Mas pode também ter a ver com a suspeita de que a organicidade e a revelação daquelas "forças ativas" apontariam para o fracasso potencial do pacto liberal, trazendo à tona a necessidade da "recuperação do desígnio ou da missão históricos", como valentemente os nomeou Richard Morse, que, poderíamos imaginar a essa altura, terá sido quem mais longe levou a reescrita de Raízes do Brasil, ainda que em O espelho de Próspero não se encontre uma única alusão a Sérgio Buarque de Holanda.

Se descontarmos a acrimônia de Morse, que radica no seu desencanto com a consciência liberal norte-americana, mas também no escárnio adorniano com os Estados Unidos, veremos que $O$ espelho de Próspero pode servir de espelho a Raizes do Brasil. Um espelho que deforma e estende o que, no ensaio de Sérgio Buarque, permanece subentendido, ou talvez simplesmente desentendido. Ao buscar compreender, mapear e avaliar as opções intelectuais que, na pré-história das mentalidades modernas, teriam dado origem às "encruzilhadas" do pensamento político europeu, o historiador norte-americano não esconde, em momento algum, sua profunda simpatia pela "opção ibérica". Como se o "esforço bem sucedido" de transplantação da cultura européia, nas palavras da primeira edição de Raízes do Brasil, fosse resgatado por Morse, que aprofunda e imagina as consequências de uma civilização que seguiu caminho diverso daquele trilhado pelos "povos protestantes", em especial a Inglaterra. Na sua lapidar e provocativa formulação: "Há dois séculos um espelho norte-americano tem sido mostrado agressivamente ao Sul, com consequências inquietantes. Talvez seja a hora de virar esse espelho" 43 .

Resumindo, pode-se supor que o encantamento de Morse pela via ibérica provenha da possibilidade de enxergar nos "escolásticos medievais" (e nos galhos que, lançados, florescerão no neotomismo, de ilustre presença entre pensadores ibéricos) uma sensibilidade ao papel da conjetura e da hipótese na construção do pensamento, contra o que seria, na ciência "moderna", o desejo de demonstrar uma "certeza final, a despir totalmente a realidade" 44 . Talvez estejamos muito próximos, aqui, da observação de Sérgio Buarque de Holanda em Raízes do Brasil, de que a "Escolástica na Idade Média foi criadora porque foi atual". Somando força aos argumentos expostos, sabemos contemporaneamente o quanto se pode aprender com a história intelectual
[42] Coelho, João Marcos. "Entrevista: Sérgio Buarque de Holanda. A democracia é dificil: as observações e as conclusões de um especialista com base no exame da história". Veja, 28 jan. 1976. Cf. também Souza, Laura de Mello e. "Corpo e alma do Brasil: entrevista com Sérgio Buarque de Holanda". Novos est. - Cebrap, $\mathrm{n}^{\circ} 69$, 2004, p. 10.

[43] Morse, Richard. O espelho de Próspero: cultura e idéias nas Américas. Trad. Paulo Neves. São Paulo: Cia das Letras, 1988, pp.13-14.

[44] Ibidem, p. 35 . 
[45] Ibidem, pp. 135-37.

[46] A questão é retomada num artigo de resposta às críticas de Simon Schwartzman a $O$ espelho de Próspero, quando, no espírito ensaístico que abraça com convicção, o historiador norte-americano se confessa "atraído pela exploração lúdica da consciência humana", conclamando, em sua defesa, um arco de autores que preservariam "a função do homo ludens, cuja vitalidade Huizinga considerava como o ingrediente fundamental da arte, cultura e improvisação social e estava, segundo ele sentia em 1944 declinando rapidamente na Europa" (cf. Morse. "A miopia de Schwartzman". Novos Est. - Cebrap, n ${ }^{\circ} 24$, 1989 , p. 168). Tão mais interessante quanto, em artigo posterior, sobre Gilberto Freyre e Sérgio Buarque de Holanda, Morse aproximasse ambos os autores de Huizinga, embora visse em Sérgio uma tendência "clássica", contra a mentalidade "barroca" de Freyre. Cf. Morse. "Balancing myth and evidence: Freyre and Sérgio Buarque". Luso-Brazilian Review, vol. $32, \mathrm{n}^{\circ} 2,1995$, p. 52. medieval, e quanto o mundo "pré-moderno" e suas premissas enriquecem e adensam a percepção de um universo governado pelos paradigmas científicos modernos, que cotidianamente retroalimentam nossa crença na ilimitada capacidade de revelação da ciência, restringindo o campo dos possíveis à área conformada por um único círculo. A lembrança de que também o mundo regido pela ciência moderna tem suas "premissas" e pressupostos, sem os quais a própria ciência despe-se de sentido e validade, pode recordar que há outros mundos igualmente legitimáveis, sobretudo estimáveis. Descobre-se, assim, como é longeva a querela sobre os "vários mundos possíveis", discussão a um só tempo "atual e inatual", para lembrar categorias caras ao historiador brasileiro.

A sedução pela via ibérica convida o estudioso à extensão, no espaço e no tempo, de concepções - sobre o indivíduo, sobre as razões de Estado, ou sobre a possível missão dos povos - que teriam sido gestadas elaboradas numa era passada. Estaéa principal zona de coincidência entre Raízes do Brasil e Oespelho de Próspero: o reconhecimento de que uma história das Américas deve necessariamente dialogar com a história européia mais remota. Evidentemente, a fé depositada nos ibéricos e em seu universalismo supostamente mais poroso, aberto à diversidade e à variedade do gênero humano, é algo que encontra os seus extremos em Richard Morse, enquanto Sérgio Buarque de Holanda parece mais reservado. Mas é plausível que, em ambos os casos, a desconfiança em relação à matriz liberal seja o motor, a causa primeira de sua escrita. No fundo de tudo, está a desconfiança em face daquele apagamento do indivíduo, da abstração de sua singularidade.

Seguindo a intuição literária de Morse, estampa-se o problema no contraponto entre T.S. Eliot e Mário de Andrade, entre J. Alfred Prufrock, com sua "personalidade irreparavelmente lesada", e o Mário de Andrade arlequinal que grita e chora (impotente, nunca é demais lembrar) na metrópole desvairada. A "generalizada cidade ocidental" de Eliot encontra-se e revela-se, empobrecida, no espelho da São Paulo todavia encantada de Mário. Anuncia-se aí, na interpretação de Richard Morse, a inarredável simpatia pelo outro lado do espelho, tomado em sua amplitude latino-americana, ou ibero-americana: o coronel Aureliano Buendía contra o coronel Thomas Sutphen, a Macondo de García Márquez contra o condado de Yoknapatawpha, de Faulkner. Na cristalina e quase cândida visão do historiador norte-americano, uma "cisão entre as sensibilidades estética e científica, que em Mariátegui estavam unidas, deslocou para os romancistas, poetas e artistas ibero-americanos o peso da responsabilidade de expressar seu mundo como centro e não como periferia" 45. Em Morse, o plano poético prenuncia e acolhe as soluções que jamais se realizaram no plano político ${ }^{46}$. 
Como derradeiro problema, especialmente provocativo em 1936, restava a relação entre o indivíduo e o Estado, ou a natureza mesma do Estado. Não se trata, contudo, de simplesmente dar mais uma volta ao empoeirado disco que por vezes ainda se impõe aos nossos ouvidos, quando se discute a maior ou menor presença do Estado na vida dos cidadãos. Regressando à preocupação de Sérgio Buarque de Holanda quando discutia Carl Schmitt, trata-se muito mais de ousar perceber o Estado não como criatura neutra, mas como dotado, em seu âmago, de uma missão, encarnando o que Richard Morse, referindo-se à época dos "soberanos católicos", identifica como a "responsabilidade da eleição de objetivos comuns", que na Inglaterra fora, segundo ele, "retirada do Estado e atribuída, num espírito de pluralismo occamista, a um mercado supostamente 'livre' de idéias e prescrições privadas, agora tratadas como 'mercadorias'" 47.

Exagerando um pouco nas metáforas, creio que aí atingimos o terreno lodoso que o leitor de Raízes do Brasil costuma evitar. É que a história política do século XX terá revelado, à saciedade, o potencial desastre do Estado que encarna uma "missão". No quadrante latinoamericano, nossa expertise em ditaduras autoriza-nos quiçá a recuar prudentemente diante de quaisquer tentativas de investir o Estado de uma organicidade inconsútil, que logicamente o torna portador da missão coletiva, no momento em que o aparato estatal se revela como a forma congênita das "forças ativas" da sociedade, espécie de soberano protetor da potencial boa ordem sociológica da terra, como bem poderia sugerir um Oliveira Vianna.

Bebendo em fonte hegeliana, Sérgio Buarque de Holanda percebia o Estado como "criatura espiritual", que se "opõe à ordem natural e a transcende". O desafio, entretanto, estava na definição do contorno do corpo social, de suas necessidades intrínsecas, ou, jogando ainda uma vez com as palavras de Morse, de seus "desígnios". Em defesa de Sérgio Buarque, há que lembrar que essas "formas superiores da sociedade" não são concebidas como uma "ordem" finalmente atingida e revelada. Ao contrário, ainda no espírito do jovem modernista, tais formas da sociedade "emergem continuamente das suas necessidades específicas e jamais das escolhas caprichosas" 48 . Há algo vivo e irrequieto nessas nunca suficientemente explicadas "necessidades específicas".

Ao fim, porém, um interessado e renitente leitor de Weber poderia perguntar, diante da missão redentora dos povos ibero-americanos, sustentada por Richard Morse, e diante da inquietação de Sérgio Buarque de Holanda com o futuro da gente de ascendência ibérica: será que no fundo da reação à despersonalização do indivíduo não estará a incapacidade de viver as encruzilhadas do "mundo moderno" em todas as suas conseqüências? Será que a luta com o desencantamento não esconde, no fundo, o desejo de buscaro sentido ali onde ele já se desfez? A
[47] Morse, O espelho de Próspero, op. cit., p. 38 .

[48] Holanda, Raizes do Brasil, op. cit., p. 208. 
[49] Cf. Schwartzman, Simon. "O espelho de Morse". Novos est. - Cebrap, $\mathrm{n}^{\circ} 22,1988$, pp.185-92; Morse, "A miopia de Schwartzman", op. cit.; Schwartzman. "O gato de Cortázar". Novos est. -Cebrap, $\mathrm{n}^{\circ} 25,1989$, pp. 191-203. Entre os comentários que suscitou a polêmica, destaco Merquior, op. cit.; Arocena, Felipe. "Ariel, Caliban e Próspero: notas sobre a cultura latino-americana". Presença, no 15, 1990, pp. 92-109; Velho, Otávio. "O espelho de Morse e outros espelhos". Estudos Históricos, vol. 2 , $\mathrm{n}^{\circ}$ 3, 1989, pp. 94-101; Oliveria, Lucia Lippi de. "Anotações sobre um debate". Presença, n 16, 1991, pp. 26-41; Bomeny, Helena. "Saudades do Brasil de Richard Morse" <http://sitemason.vanderbilt.edu/files/fmglDy/ Bomeny\% 20Helena\% 20Maria\% 202.doc), acessado em 12/08/2008. Sobre Morse, ver o número especial da Luso-Brazilian Review, vol. $32, \mathrm{n}^{\circ}$, 1995, organizado por Thomas Cohen e Dain Borges.

[50] Schwartzman, "O espelho de Morse", op. cit., pp. 186-192.

[51] Morse, "A miopia de Schwartzman", op. cit., pp. 168,176 .

[52] Tenorio, Mauricio. "Profissão: Latin Americanist: Richard Morse e a historiografia norte-americana da América Latina". Estudos Históricos, vol. 2, $\mathrm{n}^{\circ} 3,1989$, p. 108. busca desesperada do sentido, por seu turno, não poderia abrir as vias para uma nova espécie de intelectualização quase religiosa, com novos fins e novos meios? Não há, na refutação da via "moderna", o perigo de forjar mais uma racionalização férrea, com a sacralização de uma outra ética? Que significa, ao fim, a convicta recusa da visão agonística de um mundo em que o indivíduo perde a sua fibra, para tornar-se uma peça a mais na maquinaria vigente?

Se de fato há tal recusa, não cabe perguntar apenas pelas suas conseqüências. Há que inquirir-lhe também o sentido.Atélá, talvez valha a pena continuar respondendo aos ventos do Norte com novos moinhos. Afinal, o reencantamento do mundo é um caminho imaginário que Raízes do Brasil não chega a postular, mas que leitores interessados podem perfeitamente trilhar.

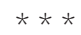

O debate que envolveu o autor de O espelho de Próspero e Simon Schwartzman no final da década de 1980, logo após a publicação do livro em português, foi já analisado em detalhe49. Ainda assim vale a pena lembrá-lo, já que em meio às farpas tocaram-se alguns pontos nevrálgicos da argumentação de Morse.

Schwartzman percebe, no livro "profundamente equivocado" que seria $O$ espelho de Próspero, uma "nostalgia pela totalidade e pelo transcendente", como se nele se escondesse um vicioso "milenarismo soreliano". Retenho aqui, à guisa de conclusão, o aspecto propriamente mítico desse reencontro daquilo que, desde a perspectiva de Schwartzman, seria uma idealizada "essência milenar perdida" 50.

É bastante significativo que, em resposta a "O espelho de Morse", o historiador norte-americano não esconda (num artigo publicado em julho de 1989, no calor da corrida eleitoral em que Lula despontava como forte candidato à presidência da República) certa esperança profética no pleno desenvolvimento do curso histórico. É impressionante a utilização abundante que Morse faz do tempo futuro ("terão de ocorrer inevitavelmente", "fatalmente ainda ocorrerá" etc.), e a convicção quase vindicativa no porvir: "o povo brasileiro como um todo, ainda conservando sua vitalidade, está tomando as rédeas nas suas mãos" ${ }^{51}$.

Antes de desqualificar a resposta de Morse como simples laivo populista, talvez seja necessário analisar o que está em questão no debate. Mauricio Tenorio, na esteira da publicação de $O$ espelho de Próspero, provocativamente sugere que se poderia considerar Morse "um flamboyant da historiografia norte-americana da América Latina" 52 . O mais interessante, no entanto, é a recuperação do contexto ideológico e teórico em que se teria gerado a visão que conforma o livro polêmico: 
[...] quando Morse fala da "tradição diferente", da necessidade de reconhecer na América Latina uma "nova ideologia", simplesmente está fazendo coro (de muito bom timbre) com os tons que ressoam desde Lévi-Strauss e Eliade até Marcuse, Adorno, Foucault e Dumont. E uma das funções fundamentais destes ecos está contida na revalorização do mitico, fator que ganha categoria de forma do conhecimento e vida, título que está no mesmo nível do conhecimento científico53.

No fundo de tudo estaria, então, a "revalorização do tradicional", ou a "crítica à modernidade" de uma parte das ciências sociais e da historiografia elaboradas nos Estados Unidos a partir, sobretudo, do final dos anos de 197054. Talvez a idéia de um "regresso" seja demasiado simplista para compreender o alcance da luz que Morse projeta sobre a história intelectual ibérica em sua longa duração. Mas há aí, em meio às provocações de parte a parte, a percepção da relação singular que o seu pensamento guarda especialmente com a religião. Uma "hermenêutica" peculiar, ou uma relação diversa com a tradição, para ecoar a arguta leitura de Otávio Velho55.

O que nota o antropólogo brasileiro, apoiado em Metz, é que a secularização e a conseqüente dessacralização do mundoé uma forma de separar-se, afinal, daquela esfera transcendente que se projeta sempre para um além, e que lá se resguarda ${ }^{56}$. Uma esfera, porém, que a todo instante ameaça regressar. Em termos caros a Morse, que recendem a Dumont e apontam para sua reflexão já posterior a O espelho de Próspero,é o holismo que contrabalança o individualismo57.

Em via diversa, pensando na história de longa duração das ciências sociais latino-americanas - diante da qual afinal Morse igualmente se posiciona -,é difícil esquecer que a partir dos anos de 1950 e, sobretudo, na década seguinte opera-se uma profunda crítica à modernização, ou mais exatamente aos seus efeitos destrutivos, que a periferia, mais do que qualquer outro espaço, saberia compreender. Isto é, a partir de meados do século passado há essa viragem que permite alterar bruscamente os ponteiros das análises que tomavam a realidade latino-americana como refratária, em si mesma, à modernização. Reafirmando o imaginário latino-americanista, o continente entregava-se à vertigem de um projeto alternativo, ou ao sonho de uma modernidade autóctone. Na trilha épica dos revolucionários ou na sanha abnegada dos reformistas, a modernidade brilhava sob todas as formas, mesmo e ainda antes que Cuba ensejasse a fantasia de um desvio radical.

Além do mais, a possibilidade de que ao longo do século XX a periferia ganhasse foros de centro criador encontra em cheio propostas anteriores, que apontam para os mais arraigados desejos modernistas. Neles, isto é, nessa tradição intelectual que Morse perscruta e recebe com regozijo crítico e liberdade poética (que se pense no tom joco-
[53] Ibidem, pp.119-120.

[54] Ibidem, p. 120.

[55] Velho, op. cit., p. 96 .

[56] Ibidem, p. 99

[57] Cf. Morse. A volta de McLuhnaíma. Trad. Paulo Henriques Britto. São Paulo: Cia das Letras, 1990, pp. 161-204. Uma análise circunstanciada dessa visão redentora da América Latina deveria levar em conta também a juventude de Richard Morse na Universidade de Princeton, onde, segundo relata o próprio historiador, Augusto Centeno lhe "abriu os olhos para García Lorca, San Juan de la Cruz, Ricardo Güiraldes", e onde estava Américo Castro, "o grande homem da geração de 98 na Espanha" (apud Bomeny, op. cit., s.p.). 
[58] Cf. Morse, A volta de McLuhnaí$m a$, op. cit., pp. $247-78$.

[59] Brioso, Jorge. "De la desaparición de los oráculos y de la muerte y resurrección de los dioses: lo sagrado y lo profano en la obra de Rubén Darío". In: Roque Baldovinos, Ricardo (ed.). Hacia una historia de las literaturas centroamericanas. Guatemala: $F \& G$, no prelo. sério do seu brilhante e hilário "McLuhnaíma, The solid gold hero ou o Herói com bastante caráter, uma fuga") ${ }^{8}$, residia já a miragem de uma reversão radical da relação de dependência - palavra que, não por caso, logrou tanto prestígio na região.

Talvez a metáfora mais forte de Morse, para quem o "espelho" deveria ser invertido (uma teleologia reversa) encontre aí sua origem, nessa aposta algo destemida - sempre um pouco quixotesca, é verdade no modelo e nas propostas de uma sociedade supostamente desviante em relação aos pactos tradicionais da modernidade ocidental. Outro Ocidente, outra América, outra Europa, outra geografia enfim, a desenhar um futuro alternativo que parte da crença e da aposta em um passado singular, o que leva a imaginação luxuosa do historiador a formular o paradoxo de um passado promissor.

Para finalizar, convém trazer Raízes do Brasil de volta ao foco. Claro está que o ensaio de Sérgio Buarque de Holanda não é O espelho de Próspero, embora a confiança no futuro universal da América Latina seja algo que, no quadrante brasileiro, encontrara já sua plena justificação entre os "nossos" modernistas, inclusive o jovem Sérgio, que vimos reagir tão visceralmente ao "empirismo frio e prosaico" da América do Norte.

Penso que o contraste aqui proposto possa ajudar a compreender, enfim, que a secularização é ainda um tema central para todos nós, latino-americanos ou não. A questão é que a "desmitologização do mundo" converte a literatura, e com ela os grandes ensaios de interpretação nacional e regional, em uma constante reconstrução do enigma que a mesma secularização promete desvendar e anular. Penso aqui na proposta de Jorge Brioso que, tendo Rubén Darío em mente, pretende "recuperar os diferentes cenários desde os quais os textos modernistas latino-americanos, que assumem sua condição profana e desencantada, incorporam o enigma, a revelação, o sentido do sagrado" 59 .

Como explicar Raízes do Brasil, então? Como e onde situar o ensaio de Sérgio Buarque de Holanda nessa linha ampla que vai da secularização ao pleno reencontro do mito?

É interessante que um livro como Raízes do Brasil desperte as mais diversas reações, e as mais extremas leituras. Se de um lado é possível imaginá-lo como um verdadeiro "prefácio" à modernidade, de outro, pergunto-me, após contrastá-lo às elucubrações de Richard Morse, se não é possível supor que Raízes do Brasil abra afinal as suas próprias vias para uma visão reencantada do mundo. Quando menos, não seria possível supor que, ao perscrutar a secularização, o livro de Sérgio Buarque paradoxalmente termina por elevar a América Latina à categoria de enigma? Como se, weberianamente, o desencantamento tornasse a busca impossível do sentido mais angustiante e urgente do que nunca. 
Talvez Ángel Rama tenha uma resposta satisfatória, que, aliás, é menos uma resposta que um programa de pesquisa. No prólogo à edição da poesia e prosa de Darío para a Biblioteca Ayacucho, o crítico uruguaio sugeria que o poeta "de um lado segue crendo no 'culto da selva sagrada, o deus grande e universal, da lei misteriosa e potente que rege tudo'; de outro, vai reconhecendo o fracasso do projeto em termos românticos"6o. É então que Darío, lembra ainda Rama, encontra em Wagner a solução para o conflito:

Haveria outro modo de conservar a selva que não fora à mercê do retrato do natural. Consistiria em uma leitura de segundo nível que a reconstruiria [...] mediante o estabelecimento, já não de imagens, senão de valores que fossem racionalizações interpretativas passiveis de expressar-se em signos culturais $[\ldots]^{61}$.

Haveria, em Raizes do Brasil, algo desse movimento substitutivo, que recobre o enigma com a roupagem racionalizante da grande "interpretação"? Será que os tipos, metodicamente desenhados, servem apenas à tarefa de corroborar a "nossa" misteriosa "contribuição ao mundo"? Serviria o discurso, entretecido nos argumentos racionais, a recordar tão-somente que o enigma está sendo resguardado até um futuro que só o poeta sabe quando e como virá? Mas como ler o vaticínio letal que Sérgio Buarque de Holanda lança sobre o "homem cordial"? Que é feito desse "herói" que resiste, e cuja dor "só Deus" e o poeta sabem "como dói"? ${ }^{62}$.

Espero que o contraste entre O espelho de Próspero e Raízes do Brasil resulte proveitoso, nisso queé a lembrança do talhe nem sempre "apolíneo" do livro de Sérgio Buarque de Holanda ${ }^{63}$. Corte não-apolíneo que, em sua paixão latino-americanista, o seu par norte-americano pode revelarem toda extensão e alcance, por ter afinal mergulhado sem qualquer pejo na verdade continental de poetas e romancistas. Talvez seja tempo de revisitar Raízes do Brasil, não mais apenas para buscar sua coerência interna ou sua preciosa arquitetura, mas sim para sondar as profundezas escuras que esse ensaio luminoso dissimula.

PEDro Meira Monteiro é professor de Literatura Brasileira no Departamento de Espanhole Português da Princeton University. É autor de A queda do aventureiro (Editora da Unicamp, 1999) e Um moralista nos trópicos (Boitempo, 2004), entre outros. [6o] Apud ibidem.

[61] Ibidem.

[62] Valho-me dos versos finais da canção de Caetano Veloso em Cê (Universal, 2006), “O herói”.

[63] A utilização das categorias nietzschianas para a compreensão de Raízes do Brasil foi proposta por Luiz Dantas ("Prefácio". In: Monteiro, A queda do aventureiro, op. cit., pp.15-20).

Recebido para publicação em 29 de janeiro de 2009.

\section{NOVOS ESTUDOS}

CEBRAP

83, março 2009

pp. 159-182 